\title{
STRUCTURING LIMINALITY: THEORIZING THE CREATION AND MAINTENANCE OF THE CUBAN EXILE IDENTITY
}

\author{
Jaclyn Colona \\ Florida International University \\ And \\ Guillermo J. Grenier \\ Florida International University
}

Structure and liminality are pervasive epistemic concepts in the social sciences. Structure is one of the most important elements in the discourse of social science, signifying "patterns" of "rules and resources, recursively implicated in the reproduction of social systems" (Giddens, 1984: 377) ${ }^{1}$. Liminality, from the Latin limen, meaning "threshold", was first conceptualized as a social state by anthropologist Arnold van Gennep in his seminal work, Les rites de passage (1909) but was popularized and expanded by Victor Turner (Turner, 1969). Liminality for Turner consisted of a separation from, or suspension of, the objective structures of society, such as rank, class, kinship ties, and gender. The liminal period is conceptualized as transitory; an "interstructural state" in which an individual or group of individuals abandon (willingly or grudgingly) a specific social state, characterized by specifically structured interactions, but have not yet entered (or re-entered) the newly prescribed social state and its accompanying responsibilities and status. In the liminal stage, the subject's identity is redefined under conditions that have "few or none of the attributes of the past or coming state" (Turner 1969:94). The liminal individual or groups are "neither here nor there; they are betwixt and between the positions assigned and arrayed by law, custom, convention, and ceremony" (1969: 95).

Does the concept of liminality assist in our understanding of the dynamics of the Cuban-American diaspora? In arguing that it does, we posit that liminality is, indeed, a state where subjects find themselves "betwixt and between"-but structurally so. That is, liminal conditions can be lasting, maybe permanent, elements of group identity. The

1 Turner defined structure as "a more or less distinctive arrangement of specialized mutually dependent institutions and the institutional organization of position and/or of actors which they imply" (Turner, 1969: 166-167). Elsewhere, he follows Robert Merton and defines it as "the patterned arrangements of role-sets, status-sets, and status-sequences" consciously recognized and regularly operative in a given society (Turner, 1974: 236-237). 
liminality of exile is real in its interstitial nature but rather than being characterized by anti-structure, it is structurally established by social forces that are themselves permanent (laws, policies, geopolitical forces). Turner acknowledged the existence of social settings where relationships are established to maintain the nature of liminality, such as monasteries and hippie communes. These relationships can begin as transitionally liminal, yet solidify into social structures under certain conditions. The case of Cuban exiles in Miami illustrates how a liminal exile identity can be solidified by structural forces within the community.

In this article, we examine the exilic experience of the CubanAmerican community in South Florida through the dual concepts of structure and liminality. We postulate that in the case of this exilic diaspora, specific structures arose to render liminality a persistent element of the Cuban-American identity. The liminal, rather than being a temporal transitory stage, becomes an integral part of the group identity. This paper theorizes and recasts the Cuban-American exile experience in Miami as explicable not only as the story of successful economic and political incorporation, although the literature certainly emphasizes this interpretation, but one consisting of permanent liminality institutionalized by structural components of the exiled diaspora. We argue that the story of exemplary incorporation so prevalent in the academic literature is a result of structured liminality. We apply Turner's conceptualization to the creation and maintenance of the Cuban-American Exile Identity (Grenier and Perez, 2003). While testing the theoretical postulates is beyond the scope of this article, we interpret previous research through our new theoretical lens.

\section{On Liminality ANd Exile}

The concept of liminality has been used to clarify the social condition of a variety of populations, always emphasizing the transitional elements involved. The concept has been particularly helpful in underscoring the status of migratory populations (Traphagan, 2000; Menjívar, 2006; Chavez, 1991; Yang, 2000) and it has been used to understand the situation of a broad range of transitional stages for individuals and groups. The power of the concept also has been applied to analyze instances of chronic illness (Little, Jordens, Paul, Montgomery and Philipson, 1998; Deegan and Hill, 1991), employment status (Garsten, 1999; Czarniawska and Massa, 2004), organizational behavior (Tempest and Starkey, 2004), the development of the self (Noble and Walker, 1997), tourists and strip clubs (Ryan and Martin, 2000), gender and transgender identities (Besnier, 1994 and 1997; Coggeshall, 1988), post-industrial work ideologies among high school students (Bettis, 1996), the psychological effects of menstruation (Derr, 1982), physical 
disability (Murphy, Scheer, Murphy and Mack, 1988) and labor strikes (Rothenbuhler, 1988).

In these and other studies, liminality is seen as part of a process that is unproblematic. Liminal states are transitional states where old structures are suspended and new ones are yet to be introduced. Implicitly or explicitly, the studies accept Turner's definition of structure which, following Robert Merton, emphasizes the "role-sets, status-sets and statussequences" operating regularly in a given society (Turner, 1974: 236237). Liminality is a transition between status-sequences of a given society; a point where old hierarchies no longer define the situation and new definitions await. Much of the power of the concept comes from this postulation of a period of "anti-structure." In the absence of hierarchical structures, new forms of social relations arise. Social solidarity emerges as a form of anti-structure or, in Turner's term, "communitas": the expressions of anti-structure in society ${ }^{2}$. Communitas is an experience arising from the condition of liminality that serves to unify and bond the liminaires allowing them to transcend structural relationships. The absence of structure allows for the operation of two distinct social forces: the creation of an environment of equality among the liminaires and a condition of timelessness, where all activity is interpreted as "the same" until a re-integration into social structure is achieved. While in the liminal state, human beings are stripped of anything that might differentiate them from their fellow human beings. Communitas is a "moment in and out of time;" an eternal now that precedes the re-integration into structured social processes (Turner, 174: 237-239).

To understand the process of exilic identity formation, we find useful Benedict Anderson's (1983) notion of "imagined communities" and Maurice Halbwachs' concept of "collective memory" (1992). For Anderson (1983: 15-16), group identity creation is an act of imagination; because "Members of modern nations cannot possibly know all their fellow-members, and yet in the minds of each lives the image of their communion. . . [The nation] is imagined as a community, because, regardless of the actual inequality and exploitation that may prevail in each, the nation is always conceived as a deep, horizontal comradeship." The same can be said for the experience of exile. The vertical diversity and stratification of the country of origin (class, ethnic, racial hierarchy) is narrowed by the experience of exile and the often contentious pluralism constituting civil society in the country of origin are recreated in the

2 Another group, marginals belong to two or more social or cultural groups and "like liminars are also betwixt and between, but unlike ritual liminars they have no cultural assurance of a final stable resolution of their ambiguity" (1974: 233). We argue that Cubans are not marginal in this sense since their ambiguity is resolved by forces which "structure" their liminality. 
imagined "exile community" conceived "as a deep, horizontal comradeship."

For Halbwachs, individuals have personal histories, but collective experiences can only be made relevant by social institutions designed to keep and transmit a collective memory of things past. Collective actions such as storytelling, rituals, festivals, commemorations of events and personalities, all keep a collective, and selective, group identity alive. The process is not automatic. The institutions in charge of maintaining alive the memories are selective in what is remembered as well as what is forgotten. The selectivity is driven by the needs of the present moment; the historical, temporal development of the community and its needs. The present establishes the importance of the past. In this way, the past is constantly being recreated to meet the needs of the present generation. Collective memory binds the members of the group to each other and to the past that created their present bonds (Halbwach, 1992). The liminality of exile is framed by the force of an imagined community that recreates a memory of a past that binds its members in a present struggle to recuperate it. The world of the imagined community of exile exists only in the memories of that community. The forces of history continue to reshape the homeland even as its past lives in the imagined memory of exiles.

Liminal states involve one or all of three kinds of separation: spatial, temporal, and social/moral (Turner 1979, 41). This multi-dimensionality of liminality is of particular significance to groups or individuals in exile. As in all diasporas, spatial structures are ruptured and the migrant is alienated from the temporality characteristic of economic, political, cultural and social nationality. But exilic groups are a special kind of diaspora; a diaspora characterized by its political dimension. Exiles have been dispersed from an original center to two or more foreign locations, like other diasporas. But the dispersal is motivated by the group members' critical stand towards their homeland's political, social, economic or cultural environment. The dispersal might be forced or voluntary but in either case, exiles are "reluctant leavers driven out by the prospect of an unacceptable fate" (Rose 1981, 8).

The "push" factors motivate exile migrations while "pull factors" motivate immigrant migration (Stein 1981, 322). In differentiating refugees from voluntary migrants, Kunz $(1973,130)$ highlights the refugees' "reluctance to uproot. . .and the absence of positive original motivations to settle elsewhere" as distinguishing characteristics of refugees.

Once in the hostland, exiles retain a collective memory about the homeland. This collective memory is reinforced by commemorative rituals and geographies which keep alive social relations, attitudes and dispositions. Exiles, unlike immigrants, do not desire integration into the 
hostland. Not only do they regard their ancestral homeland as their real and ideal home to which they should return, but they consider themselves the "other" in the hostland; not fully accepted- culturally, economically, politically, and socially. Edward Said, in similar vein to Turner, conceptualized exile as "a median space" where the exile is "neither completely at one with the new setting, not fully disencumbered of the old, beset with half-involvements and half-detachments, nostalgic and sentimental on one level, an adept mimic or a secret outcast on another" (Said, 1996: 49). This condition reinforces the motivation to commit the collective energy to the maintenance of the homeland as a lived experience in the hostland as well as a continuation of the true traditions of the original homeland ${ }^{3}$.

The experiences which create and identify exilic populations place the group members in a "betwixt and between" state, free of structures that previously bound them (nation-state, class standing, social status) but with reintegration a complex proposition. Unlike the linear, integrative process proposed by Parks during the early 20th Century- (contact/ conflict/ cooperation/assimilation) — which integrates migrants into the structures of the hostland, exiles conceptualize their rootlessness differently. The exiles do not desire to be integrated into the hostland. They desire to exit their exile liminal state by reintegrating into the homeland structures that preceded the exile experience. The process is not towards integration into the hostland; it is to return home. But they are "structurally invisible" to the homeland's emerging "definitions and classifications" (Turner, 1974: 232), making integration into hostland structures inevitable.

Most of the literature on the Cuban success story focuses on this integration. But the liminality of exile persists. The exile identity is not derived from the historically established culture of the new society, even as they are integrated into its structures. Their security comes from hanging on to liminality; to the exile vision of return.

Although not previously framed in these terms, there is ample evidence on the creation of communitas as a dynamic of liminality in the early period of the Cuban exile experience in the United States (Garcia, 1996; Gonzales-Pando, 1998; Grenier and Perez, 2003; Portes and Stepick, 1995). From the many conflictive ideological strands existing in Cuba, a common identity as exiles emerged. The political culture of the island was contentious and often violent. Dozens of political parties vied for control of the state and the support of civil society organizations (Perez-Stable, 1993: 36-60). The 26th of July Movement led the Revolution but it was made possible by the discontent of most of the political actors.

3 See Safran's characterization of diasporic communities (1990). 
Practically every civil society organization and political party took part in the anti-Batista movement and stood to benefit from the Revolution. Within a few years, however, the 26th of July Movement redefined itself. Many of the supporters of the Revolution became disaffected. Some took up arms, others were ostracized, but most fled to create the foundation of the Cuban exile community in the United States.

Political tendencies separated Cubans in the US from Cubans on the island. In exile, however, these tendencies were subsumed under their common identity as exiles. The political tendencies of the founding wave of exiles can be categorized as Batistianos, Conservatives and Liberals. The Batistianos arrived immediately after the revolution. The Conservatives followed soon after, entering the United States between 1960 and 1961. Most of the Liberals arrived later in the decade but probably were the dominant group in the 1962 to 1964 migration wave (Forment, 1989:54). Given the pluralistic ideological landscape, the rise of a coherent political identity among those fleeing the Revolution was not inevitable. The process entailed the convergence of structural, geopolitical forces as well as the solidification of an "exile" identity that cut across ideological boundaries established in the Cuban context. A sense of communitas emerged: a clear identity as exiles; a common and unambiguous experience of having "lost" their homeland and having an equal stake in regaining it (Grenier and Perez, 2003).

The exile identity was temporally interstitial. The exilic experience would be a temporary break and "soon" the exiles would become exexiles and re-integrate into the structures of the home country. Exile movements were an integral part of Cuban history and, given that the United States had always weighed in previously, the initial cohort of exiles felt confident that their stay in the U.S. would be temporary; a "time in which the structural view of time is not applicable" (Turner, 1974: 238). Most exiles arrived in the U.S. with tourist visas. As Garcia states, "they were in the U.S. not to make new lives for themselves as norteamericanos, but to wait until they could resume their previous lives back home" $(1996,15)$.

\section{On the Cuban Exile Diaspora: Exile as a Lasting Liminal Structure}

Ultimately, individuals and groups can self-identify as exiles but whether this identity and status is acknowledged or not in their "host societies" depends on the nature of the structured political relations between their country of origin and their country of destination. That is, the exile identity is a structured, constructed phenomenon; a result of social relations between people and institutions, mediated by the political relationship between their countries of origin and destination; what is politi- 
cal or "exile," and what it is not, therefore, depends on the nature of those relations. Exile can become a political role, a bargaining chip, a marketable identity, a type of capital.

The early 1960s was a good time to cash in exilic capital in the United States, especially if the group in question was predominantly white, political migrants fleeing communism. American attitudes toward immigrants were fairly positive circa 1960 , in the wake of postwar prosperity and a period of very low immigration. There was a special sympathy for refugees fleeing from communism which was given structure by the State's decision to bestow refugee status on the arrivals. No matter if one was a member of the Communist Party in Cuba or not, if you fled the Revolution, you were a political refugee. In the U.S., groups designated as refugees are offered special governmental assistance when they arrive that is not available to other immigrant flows (Zucker and Zucker 1987).

The fortification of the exile identity was assisted by the U.S. government in some powerful ways. The U.S. government created for the arriving Cubans an unprecedented direct and indirect assistance program, the Cuban Refugee Program, which cost nearly $\$ 1$ billion between 1965 and 1976 (Pedraza-Bailey 1985, 41; Perez-Stable and Uriarte, 1990, 6). Even in programs not especially designed for them, Cubans seemed to benefit. From 1968 to 1980, Hispanics (almost all Cubans) received 46.9\% of all Small Business Administration loans in Dade County (Porter and Dunn 1984, 196).

The Cuban Adjustment Act of 1966 was perhaps the iconic manifestation of structuring liminality. The Act (Law Number 89), "adjusted" the legal status of Cubans arriving in the Unites States after January 1, 1959 (the date of the triumph of the revolution) to one of political refugees accorded the benefits of political asylum. Cubans were allotted automatic permanent residence status without the need of a review or lengthy waiting time. The Act not only grants working papers but also access to public resources, such as welfare, unemployment benefits and medical assistance.

The U.S. covert war against the Castro government provided additional structure to the exile identity. The University of Miami had the largest CIA station in the world outside of the headquarters in Virginia. With perhaps as many as twelve thousand Cubans in Miami on the CIA payroll in the early 1960s, it was one of the largest employers in the state of Florida. It supported what was described as the third-largest navy in the world and over fifty front businesses: CIA boat shops, CIA gun shops, CIA travel agencies, CIA detective agencies, and CIA real-estate agencies (Didion 1987, 90-1; Rieff 1987, 193-207; Rich 1974, 7-9). This type of structural reinforcement of a group's exile agenda contributed to 
the formation not only of a common identity but also served as seed capital for legitimate enterprises of the economic enclave.

In sum, the total benefits available to Cubans because of the exilic identity surpass those available to other U.S. minority groups. About seventy-five percent of Cuban arrivals before 1974 directly received some kind of state-provided benefits (Pedraza-Bailey 1985, 40). These benefits facilitated the incorporation of Cubans into the fabric of U.S. society. Cubans recognized that these benefits were bestowed because of their exilic, liminal existence. What might have been a liminal period preceding incorporation became a permanent element of Cuban-American reality and identity in South Florida. Liminality had its benefits.

\section{The Enclave as Liminal Space}

The benefits accrued by Cubans as refugees, a structural position accorded them by the U.S. government, were instrumental in transforming the Miami area into a social and economic ethnic enclave ${ }^{4}$. The existence and persistence of the Cuban ethnic enclave has been well established (Perez, 2001; Logan, et. al 1994; Portes and Bach, 1985; Portes and Jensen, 1989). What interests us here is how the enclave institutionalized liminality through its socio-institutional relationships.

The most important overall feature of the Cuban economic enclave in Miami is its institutional range. The variety of relationships possible among Cubans is so extensive that some claim it is possible for Miami Cubans to completely live within the ethnic community (Perez, 1993). The institutional range of the enclave was established in the decade of the 1960s and allowed for the establishment and survival of the Cuban exile culture. This process was assisted by the settlement pattern of the new arrivals. Despite the resettlement efforts of the Cuban Refugee Program to other regions to the US, most Cubans remained or returned to the Miami area. The majority settled within a four square mile area southwest of the central business district, an area that came to be known as "Little Havana." Thanks to the density of settlement, this area became a liminal space for Cuban exiles. Retail stores, restaurants, and places of worship, all became centers where discussions and rituals of exile could be performed (Garcia 1996; Gonzalez-Pando 1998).

Exiles found it easy to establish cultural boundaries in South Florida. The pressure to assimilate was reduced and the benefits of liminality were reinforced. Organizational and social networks emerged that allowed Cuban exiles to express and maintain their Cuban-ness while integrating into American society. An example of liminal relationships

4 An ethnic enclave is "a distinctive economic formation, characterized by the spatial concentration of immigrants who organize a variety of enterprises to serve their own ethnic market and the general population" (Portes \& Bach 1985, 203). 
established among exiles is the emergence of character loans. While major banks would not loan money to Cubans without collateral, which only the wealthy had, character loans became institutionalized as an exile's financial institution. Smaller banks and even private businesses loaned Cubans money or franchise fees based on their social networks within the exile community (Garcia 1996, 87; Gonzales-Pando 1998, 135).

\section{Liminal Structures and Institutions: Cuban Media and Los municipios}

Exiles, holding out the hope of recovering the homeland, strive to transplant and replicate the institutions of the country of origin, contributing to the sense of solidarity and common identity. The completeness of the enclave, gives rise to a density and diversity of relationships that we argue contribute and give value to the liminality of exile. We will focus here on what we consider to be two of the most significant structures and organizations which lend cohesion and continuity to the liminal exilic identity: the Spanish language media and the municipios en el exilio (Municipalities in Exile).

The intense and diversified entrepreneurial activity of the enclave facilitated the growth of its own Spanish-language media, which became a major conduit for an exile identity (Perez 1992; DeSipio and Hanson 1997). Tabloids, newspapers, and magazines-totaling in the hundreds by the onset of the 1970s - were published by the exiles (Garcia 1996). These Miami-based Spanish-language media are quite distinct from their English-language counterparts insofar as the central focus of their news is Cuba. This focus on Cuba is important because, as $\operatorname{Knight~}(2001,108)$ observes, the press may not be able to dictate what people think, but "it is stunningly successful in telling its readers what to think about" (quoted in Bailey and Gayle 2003, 60).

A particularly potent vehicle for disseminating the liminal exile ideology was the political tabloids, or periodiquitos, distributed by Cuban businesses. Before 1959, only the Nicaraguan owned Diaro Las Americas, provided news in Spanish. By the end of the decade hundreds of newspapers, magazines and tabloids, with names like Patria (Motherland), Conciencia (Conscience), El clarin (The bugle), Centinela la libertad (Sentinel of liberty), and El gusano (the Worm, the pejorative term used by Fidel to refer to the exiles), kept the exile agenda in the public consciousness (Garcia 1996, 132-135). While the publications could be characterized as conveying a diversity of views (right-wing Batistiano, Conservative, and Liberal), they all served the purpose of communicating and interpreting the exile experience as a temporary one, characterized by a fierce anti-Castro viewpoint and maintaining alive the visions of a Cuba destroyed by a Revolution (Forment 1986, 61-63). 
The exile identity was similarly imagined and revitalized in the voices of the exile leaders broadcast through the dozens of Spanish language radio stations catering to the exile community. Spanish language broadcasts in English language stations became common in the early 1960s and the first entirely Spanish language radio stations, WQBA, " $L a$ cubanisima" (the "most Cuban"), and "La fabulosa" WFAB, were established by mid-decade. The first Cuban-owned station, Cadena Azul, came online in 1973. By the 1980s, over 10 Spanish language stations broadcast in the Miami area (Garcia 1996, 106).

By 1970, exiles in south Florida also had their own Spanish language TV station, WLIV-Channel 23, an affiliate of the Spanish International Network (later renamed Univision). During the 1960s and 1970s, any station that addressed the growing Cuban population would begin and end its programming day by showing images of pre-Castro Cuba and playing the Cuban National Anthem (Garcia 1996, 108). By the 1980s, Channel 23 had higher viewer ratings than any other station in South Florida. Perez (1992) concludes that the enclave's Spanish-language media have played a central role in sustaining the exile ideology and identity.

Cultural organizations catering to the growing exile community began to emerge during the early 1960s. The most significant of these organizations were the municipios en el exilio. Prior to 1959, Cuba was divided into six provinces and 126 municipios, or regional governments. The first municipio in exile was established in 1962. Eventually, 114 organizations were established to form the municipios en el exilio, even as Cuba has reorganized its political geography eliminating all of the old municipio boundaries. The organizers of the municipalities in exile do not recognize the dissolution since it was based on the 1940 Constitution, which they consider the legitimate Constitution of the island. The pre1959 municipios of Cuba exist only in exile.

The network of municipios "is the only group in exile that has united Cubans," according to the founder of one municipio. It is the "ideal vehicle to help us arrive united in Cuba" (in Garcia, 1996, 92). The organizations hoped to bridge the ideological differences within the community by appealing to the cultural bonds shared in exile. The main purpose of the organizations was to remind the members that they were Cuban Exiles, not Americans. Their ultimate responsibility was to work for the return to the island. To this day, they maintain their eyes focused on the liminality of the Cuban exile condition; a condition that can only be resolved by a return to the island, not by incorporation into the United States' social structure. Their goal is to "be the spearhead to lead the humanitarian, material and spiritual reconstruction of its fellow municipalities on the island" (Municipios de Cuba en el Exilio, 2010) 


\section{Discussion: The Persistence of a Liminal Identity}

While the Cuban-American community is changing, there remains a powerful presence of the liminal exile in the Cuban identity. That is, to be "Cuban" is to be an "exile" rather than an immigrant. The exile liminal identity has four principal and interrelated dimensions: 1) A persistent obsession with the primacy of the homeland; 2) uncompromising hostility towards the Castro government; 3) emotionalism, irrationality, and intolerance towards voices of dissent; and 4) a political alliance with the Republican Party (Perez, 1992; Grenier and Perez, 2003).

\section{Primacy of the Homeland}

In the exile liminal identity, the affairs of the homeland represent the community's foremost priority. The desire to recover the homeland is the focus of political discourse and the source of mobilization in the $\mathrm{Cu}$ ban-American community. At times, the obsession with Cuba translates into conflictive policies. Miami-Dade County was the only county in the country that had an ordinance preventing county funds from being used in any business activity involving Cuban nationals. This prohibition was redundant with the Federal trade sanctions currently in place but had a direct impact on cultural organizations working within the legal limits of the Federal trade sanctions. The ordinance was judged to be unconstitutional in 2000, but support for it did not go away. When asked in the FIU Cuba Poll 2000 if they supported the principles of the revoked ordinance, 49 percent of Cuban Americans said that they did, as compared to 25 percent of non-Cubans in Miami-Dade (Grenier and Gladwin, FIU Cuba Poll, 2000).

Recently elected Congressman David Rivera, while serving as a State Representative from Miami-Dade County, sponsored a bill banning colleges and universities in the State from using any funds from any source (state, federal, private or other) to support travel or research related costs to Cuba and other countries designated by the U.S. State Department as "state sponsors of terrorism." As of November 2010, the list includes Cuba, Iran, Sudan, and Syria. The statute was ruled unconstitutional in 2008, but a federal appeals court in 2010 overturned the ruling. Like the other six Cuban Americans in Congress, David Rivera does not apologize for focusing on the exile agenda.

\section{Uncompromising Hostility towards the Castro Government}

The goal of the Cuban exile is the overthrow of Fidel Castro. This is to be accomplished through hostility and isolation, not rapprochement. Such an ideology has been, in general terms, consistent with United States policy towards Cuba over the past 50 years. Some argue that pressure from Cuban Americans (and the importance of Florida in national 
elections) has been the major factor that has kept the U.S.'s Cuba policy essentially immutable for five decades and focused on a strategy of isolating Cuba (Barreto, et al 2002).

Certainly since 1980, when the candidacy and election of Ronald Reagan dramatically increased the participation of Cuban Americans in the U.S. electoral system, and prompted the formation of an exile lobby group in Washington ${ }^{5}$, the Cuban voting bloc has been a loyal ally of hardliners in both parties (De la Garza and Desipio 1994; Moreno and Warren 1992). The exile desire of return and reintegration into the homeland of ten manifests itself in belligerent, hardline postures. The FIU Cuba Poll 2007 found that over seventy percent of the South Florida Cuban population still favors exile led military action against the Cuban government; over fifty percent support a U.S. led invasion (Grenier and Gladwin, FIU Cuba Poll 2007).

Appealing to the liminal exilic emotions has been a tactic widely used by both Republican and Democratic candidates. It has sent two Cuban-American Republican Senators to Washington and four Republican members of Congress. Even the two Cuban-Americans? Democratic congressional delegates from New Jersey, Senator Menendez and Congressman Sires, are strong supporters of the exile agenda and typically vote with the Florida Republicans on Cuba issues.

Support for the trade sanctions against the island, the embargo, is another element of the incessant struggle against the Cuban government. The fact that nearly 50 years of trade sanctions have not brought about a change in the government does not go unnoticed. Over 74 percent of Cuban-Americans are aware that the embargo has not worked, yet 62 percent favor its continuation. (Grenier and Gladwin, FIU Cuba Poll, 2007)

\section{Irrationality and Intolerance}

Support for the embargo underscores yet another trait of the liminal political identity of Cubans in the U.S.: the importance of emotion over pragmatism. While admitting that the embargo may be ineffective, a majority in the Cuban community continue to oppose any softening of U.S. policy because of its symbolism. If the U.S. abandons its hardline stance against Cuba, Fidel Castro will have "won" the fifty year struggle. It is therefore a struggle that is based not so much on pragmatism as it is on emotion (Girard and Grenier, 2008).

Cubans-as with exiles everywhere-are not likely to be objective about a situation that has so intrinsically altered their lives and compelled them to live outside their native country. The emotional basis of the exile 
liminal identity is what makes Cubans in the U.S. take positions that everyone else judges to be irrational, as happened in the case of Elián González (see Grenier and Perez, 2003; Chapter 8). In fact, many Cuban exiles will readily, and even proudly, admit to not being rational in matters that have touched them so deeply, and will even flaunt their passionate lack of objectivity. One participant in a Miami demonstration carried a placard that read: Intransigente . . ¿ ¿y qué? (Intransigent . . . so what?).

The unfavorable side of emotionalism and irrationality is a traditional intolerance to views that do not conform to the predominant "exile" identity of hostility towards the Castro regime. Those who voice views that are "soft" or conciliatory with respect to Castro, or who take a less-than-militant stance in opposition to Cuba's regime, are often subjected to criticism and scorn, and their motives questioned. During the decade of the 1970s, violence against dissenters was a real possibility. Over one hundred bombs exploded in Miami during the decade directed at Cuban-Americans diverging from compliance with the parameters of the exile identity (Torres, 1999: 102).

Many saw the 2010 elections as a reaffirmation of the exilic identity of Cubans in the United States. One of the most popular Cuban-American bloggers categorized the elections as a referendum on the exile agenda. Despite prognostications that there is a "shift in the Cuban American community towards a less intransigent and gentler approach towards Cuba's communist dictatorship, [the November 2nd elections] show that overwhelmingly they voted for candidates who have maintained a strong opposition to rewarding the Castro regime" (de la Cruz, Nov. 15). The liminal exile identity is difficult to transform.

\section{Preference for the Republican Party}

The primacy of the homeland explains the overwhelming preference for the Republican Party, a trait that sets Cubans apart from most other Latino groups. Registered Republicans far outnumber registered Democrats among Cubans in Miami: 63 to 21 percent (Grenier and Gladwin, Cuba Poll, 2008). In the mind of a typical Cuban-American, loyalty to the Republican Party demonstrates the importance of international issues in the political agenda of Cubans (Barreto, et al 2002; De la Garza, et al 1994).

If Cuban-Americans were to view themselves as immigrants in this country, rather than as political exiles, and made judgments about political parties based upon their needs and aspirations as immigrants in the United States, they would be Democrats in overwhelming numbers. This would be true not because of the general social agenda of the Democrats but specifically because of the experience of Cuban migration. The mea- 
sures that have facilitated Cuban immigration and the adjustment of $\mathrm{Cu}$ ban-Americans in the United States - from the Cuban Readjustment Act to the Mariel boatlift- have all been enacted by Democratic administrations.

While it is beyond the scope of this paper to empirically test the major theoretical propositions presented, one particular study is worth mentioning. Girard and Grenier (2008) explored the power of the enclave and its institutions to "incubate" the exile identity which, as we theorize in this paper, is a liminal experience. The authors discovered an "enclave effect" which establishes a statistically significant relationship between the measures of the liminal exile identity and residence within the $\mathrm{Cu}$ ban-American enclave. Living in the enclave triples the odds of belonging to the Republican Party and doubles the odds of considering a political candidate's position on Cuba important for local voting purposes. The enclave effect also increases the Cuban-American respondents' support for continuing the embargo, the travel ban to the island, as well as prohibiting political contact with the Cuban government. These are key measures of uncompromising hostility towards the Castro government.

Similarly, respondents who receive most of their information from the Spanish language media are significantly more likely to hold beliefs in line with the liminal exile identity than those who do not. This is a powerful statement about the power of the exile environment and its institutions to secure the permanency of liminality (Girard and Grenier, 2008).

\section{Conclusion: The Liminality of Life on the Hyphen}

How do these dynamics translate to second and future generations? While one would expect the influence of the enclave to be a positive one in the incorporation of Cuban-Americans into the new structures of the United States, one would also expect that the insularity of the enclave, along with its density of social networks, would reinforce the Cuban cultural memory and facilitate the transmission of Cuban traits and identity, including the exile identity. The Children of Immigrants Longitudinal Study (Portes and Rumbaut, 2001) raises interesting questions about the future of Cuban identity for those living in the Miami area.

When it comes to ethnic identification, second-generation Cubans were more likely to identify themselves as hyphenated Americans than any other national immigrant group in the sample. Yet, they were also more likely to identify themselves as American than any other group and the least likely to identify themselves with a non-national identity (e.g. Hispanics). To us, this is not as surprising or contradictory as it may seem. The Cuban identity remains influenced by the exile experience. 
This influence manifests itself even as the relatively successful integration of the population establishes Cubans as the most successful "Hispanic" group in the United States. Yet Cubans do not consider themselves Hispanics. This lack of identification is twofold. Cubans are not Hispanics because they do not see their experience being structured by the experience of Hispanics, as a pan ethnic category established by U.S. historical development. Most importantly, they shun the Hispanic label because their experience as exiles and not as immigrants sets them apart from other Hispanic populations (Gonzales-Pando 1998, 89).

As a group, Cubans have experienced unusual success securing economic resources but this very success is due to their vision of themselves as not belonging to U.S. society; they are exiles. They are both integrated and transitional. A new type of relationship is being established by exiled Cubans in the process of settling in the United States-one that demonstrates characteristics of permanent liminality; of a population that does not want to integrate because they "belong" in the old country, as well as characteristics of a successful minority group working within the existing structures to secure its place.

\section{REFERENCES}

Arguelles, Lourdes. 1982. "Cuban Miami: The Roots, Development and Everyday Life of an Émigré Enclave in the U.S. National Security State." Contemporary Marxism, Summer:27-43.

Bailey, Gordon and Gayle, Noga. 2003. Ideology: Structuring Identities in Contemporary Life. Orchard Park, New York: Broadview Press.

Barreto, Matt; Rodolfo O. de la Garza; Jongho Lee; Jaesung Ryu; and Harry P. Pachon, 2002. "A Glimpse Into Latino Policy and VotING Preferences." The Tomas Rivera Policy Institute. March.

Besnier, Niko. 1994. "Polynesian Gender Liminality Through Time and Space. In Third Sex, Third Gender: Beyond Sexual Dimorphism in Culture and History, edited by Gilbert Herdt, NewYork: Zone Books. 285-328.

Besnier, Niko. 1997. "Sluts and Superwomen: The Politics of Gender Liminality in Urban Tonga." Ethnos 62:5-31.

Bettis, Pamela. 1996. "Urban Students, Liminality, and the Post Industrial Context." Sociology of Education 69:105-125.

Chavez, Leo R. 1991. "Outside the Imagined Community: Undocumented Settlers and Experiences of Incorporation." American Ethnologist. 18: 257-278.

Coogeshall, John. 1988. “'Ladies’ Behind Bars: A Liminal Gender as Cultural Mirror." Anthropology Today 4:6-8. 
Colona, Jaclyn. 2009. "On Exile and the Permanence of Liminality: The Ideology of Communitas in the Cuban American Community of Miami" Paper submitted to the American Anthropological Association. Philadelphia, Pennsylvania. Dec. 3-5, 2009. Unpublished Manuscript.

Committee on the Judiciary. 1976. "Terroristic Activity: Terrorism in the Miami Area." Hearings before the Subcommitee to Investigate the Administration of the Internal Security Act and Other Internal Security Laws. Ninety-Fourth Congress. U.S. Government Printing Office, Washington, D.C. May 6.

Czarniawska, Barbara and Carmelo Mazza. 2003. "Consulting as a liminal space." Human Relations 56: 267-290.

Deegan, Mary Jo and Michael R. Hill. 1991. "Doctoral Dissertations as Liminal Journeys of the Self: Betwixt and between in Graduate Sociology Programs." Teaching Sociology 19: 322-332.

De La Garza, Rudolofo and Luis Desipio. 1994. “Overview: The Link Between Individuals and Electoral Institutions in Five Latino Neighborhoods." In Barrio Ballots: Latino Politics in the 1990 Elections, edited by Rodolfo de la Garza, Martha Menchaca, and Luis Desipio. Boulder: West View Press. 1-42.

DeSipio, Louis, and James Richard Henson.1997. "Cuban Americans, Latinos, and the Print Media: Shaping Ethnic Identities," Press/ Politics, 2: 52-70.

De la Cruz, Alberto. 2010. "The Generational Divide that is neither generational nor divided." Alu. http://babalublog.com/2010/11/thegenerational-divide-that-is-neither-generational-nor-divided/.

Derr, Bruce. 1982. "Implications of Menstruation as a Liminal State." American Anthropologist 84: 644-645.

Didion, Joan. 1987. Miami. New York: Simon and Schuster.

Forment, Carlos.1989. "Political Practice and the Rise of an Ethnic Enclave: the Cuban American case, 1959-1979." Theory and Society 18: $47-81$.

García, María Cristina. 1996 Havana USA: Cuban Exiles and CubanAmericans in South Florida, 1959-1994. Berkeley: University of California Press.

Garsten, Christina. 1999. "Betwixt and between: Temporary Employees as Liminal Subjects in Flexible Organizations." Organization Studies 20: 601-617. 
Girard, Chris and Guillermo J. Grenier. 2008. "Insulating Ideology: The Enclave Effect on South Florida's Cuban Americans," Hispanic Journal of Behavioral Sciences, 30: 530-543.

Grenier, Guillermo. J.1994. "Los Bravos de la Politica: Cubans and the Electoral Process in Miami-the Case of the 1990 Elections." In Barrio Ballots: Latino Politics in the 1990 Elections, edited by Rudolfo de la Garza, Martha Menchaca, and Louis Desipio, 161196. Boulder, Col.: Westview Press.

Grenier, Guillermo J. 2006. "The Creation and Maintenance of the $\mathrm{Cu}$ ban American 'Exile Ideology': Evidence from the FIU Cuba Poll 2004." Journal of American Ethnic History 25: 209-224.

Grenier, Guillermo J. and Lisandro Perez. 2003. The Legacy of Exile: Cubans in the United States. Boston: Allyn and Bacon.

and Alex Stepick III. 1992. "Introduction" In Miami Now!: Immigration, Ethnicity, and Social Change, edited by Guillermo J. Grenier and Alex Stepick III, 83-108. Gainesville: University Press of Florida.

and Hugh Gladwin. FIU Cuba Poll: 1991-2008. Institute for Public Opinion Research (IPOR). Florida International University. www.fiu.edu/ ipor

Knight, G. (2001). “The Mass Media.” In New Society: Sociology for the 21st Century, edited by Robert J. Brym, 89-116. Toronto: Harcourt.

Kunz, E.F. 1973. "The Refugee in Flight: Kenetic Models and Forms of Displacement", International Migration Review 7:125-146.

Little, Miles, Christopher Jordens, Kim Paul, Kathleen Montgomery and Bertil Philipson. 1998. "Liminality: A Major Category of the Experience of Cancer Illness." Social Science \& Medicine 47: 14851494.

Menjivar, Cecilia. 2006. "Liminal Legality: Salvadoran and Guatemalan Immigrants' Lives in the United States." American Journal of Sociology 111: 999-1037.

Moreno, Dario and Christopher Warren. 1992. "The Conservative Enclave: Cubans in Florida." In Latinos in the 1988 Election, edited by Rodolfo O' de la Garzas and Louis DeSipio, Boulder, CO: Westview Press.

Municipios en El Exilio. 2010. http://www.facebook.com/group.php?gid $=2362188362$.

Murphy, Robert F., Jessica Scheer, Yolanda Murphy and Rita Mack. 1988. "Physical disability and social liminality: a study in the rituals of adversity." Social Science and Medicine 26:235-42. 
Noble, Charles and Beth Walker. 1997. "Exploring the relationship among liminal transitions, symbolic consumption, and the extended self." Psychology and Marketing 14:29-47.

New York Times. 1965. "Cuba's Refugees 'Adjust' to U.S.; Survey of Exiles Points to Waning of Anti-Castroism." December 5, 25.

Park, Robert E. 1928. "Human Migration and the Marginal Man", American Journal of Sociology 22:881-893.

Pedraza-Bailey, Sylvia. 1985. Political and Economic Migrants in America: Cubans and Mexicans. Austin: University of Texas Press.

Pedraza, Sylvia. 1992. "Cubans in Exile, 1959-1989: The State of the Research" in Cuban Studies Since the Revolution, edited by Damian J. Fernandez, 235-258 Gainesville, Fl: University of Florida Press.

Pérez, Lisandro. 1992. "Cuban Miami” In Miami Now!: Immigration, Ethnicity, and Social Change. Edited by Guillermo J. Grenier and Alex Stepick III, 83-108. Gainesville: University Press of Florida.

Perez, Lisandro. 2001."Growing up Cuban in Miami: Immigration, the Enclave, and New Generations. In Ethnicities: Children of Immigrants in America, edited by Ruben G. Rumbaut Alejandro Portes, 91-125. Berkeley, CA: University of California Press and Russell Sage Foundation.

Perez-Stable, Marifeli. 1993. The Cuban Revolution: Origins, Course and Legacy. New York: Oxford University Press.

Porter, Bruce and Marvin Dunn. 1984. The Miami Riot of 1980: Crossing the Bounds. Lexington, Mass.: Lexington Books.

Portes, Alejandro and Robert L Bach. 1985. Latin Journey: Cuban and Mexican Immigrants in the United States. Berkeley, CA: University of California Press.

Portes, Alejandro and Leif Jensen. 1989. "The Enclave and the Entrants: Patterns of Ethnic Enterprise in Miami Before and After Mariel." American Sociological Review 54: 929-49.

Portes, Alejandro and Alex Stepick III. 1996 City on the Edge: The Transformation of Miami. Berkley: University of California Press.

Rich, Cynthia Jo. 1974. "Pondering the Future: Miami's Cubans after 15 Years." Race Relations Reporter 5:7-9.

Rief, David. 1987. Going to Miami: Exiles, Tourists, and Refugees in the New America. Boston: Little, Brown.

Rothenbuhler, Eric W. 1988. "The Liminal Fight: Mass Strikes as Ritual and Interpretation" in Durkheimian Sociology: Cultural Studies." 
Edited by Jeffrey C. Alexander, 66-90. New York: Cambridge University Press.

Rose, Peter. 1981. "Some Thoughts about Refugees and the Descendants of Theseus", International Migration Review 15:8-15.

Ryan, Chris and Amber Martin. 2001. "Tourists and strippers: Liminal Theater." Annals of Tourism Research 28:140-163.

Said, Edward. 1996. Representations of the Intellectual: The Reith Lectures. New York: Knopf Doubleday.

Stein, Barry N. 1981. "The Refugee Experience: Defining the Parameters of a Field of Study", International Migration Review 15:320-330.

Stepick, Alex, Guillermo Grenier, Max Castro, and Marvin Dunn. 2003. This Land Is Our Land: Immigrants and Power in Miami. Berkeley: University of California Press.

Tempest, Sue and Ken Starkey. 2004. "The Effects of Liminality on Individual and Organizational Learning." Organization Studies 25:507527.

Traphagan, John. 2000. "The Liminal Family: Return Migration and Intergenerational Conflict in Japan." Journal of Anthropological Research 56: 365-385.

Turner, Victor 1969 The Ritual Process: Structure and Anti-Structure. New York: Aldine.

Turner, Victor. 1974. Dramas, Fields, and Metaphors: Symbolic Action in Human Society. Ithaca, NY: Cornel University Press.

Yang, Guobin. 2000. "The Liminal Effects of Social Movements: Red Guards and the Transformation of Identity." Sociological Forum 15: 379-406.

Zucker, Norman L. and Naomi F. Zucker. 1987. The Guarded Gate: The Reality of American Refugee Policy. San Diego, CA: Harcourt Brace Javanovich. 